\title{
Caracterización física y mecánica de placas de yeso con materiales de cambio de fase incorporados para almacenamiento de energía térmica mediante calor latente
}

\section{Physical and mechanical characterization of gypsum boards containing phase change materials for latent heat storage}

\author{
$\underline{\text { A. Oliver-Ramírez }}^{(*)}$, A. García-Santos(*), F. J. Neila-González(*)
}

Recepción/Received: 26-VI-09

Aceptación/Accepted: 05-II-10

\section{RESUMEN}

En esta investigación se ha diseñado y fabricado un panel de escayola que incorpora un $45 \%$ en peso de material de cambio de fase, manteniendo las propiedades físicas y mecánicas exigidas en la normativa de aplicación para yesos de construcción (UNE EN 13279 y referencias a la RY 85). Así, un panel de $1,0 \mathrm{~m}^{2}$ y $1,5 \mathrm{~cm}$ de espesor, contiene $4,75 \mathrm{~kg}$ de PCM, cantidad muy superior a la conseguida hasta la fecha $\left(3 \mathrm{~kg} / \mathrm{m}^{2}\right)$. Para ello se ha mejorado previamente sus prestaciones mecánicas y físicas mediante adiciones binarias: fibras de polipropileno y dispersión de melanina formaldehído.

Este porcentaje es capaz de almacenar en $1,5 \mathrm{~cm}$ de espesor cinco veces la energía térmica de un panel de cartón yeso con el mismo espesor y la misma cantidad que una fábrica de $1 / 2$ pie de ladrillo hueco, en el rango de temperaturas próximas a la de confort (20-30 ํㅡ).

Palabras clave: yeso, PCM, energía térmica, almacenamiento, calor latente, propiedades físicas, propiedades mecánicas.

\section{SUMMARY}

This article describes the design and manufacture of a gypsum board which, despite its $45 \%$ wt content of phase change materials, meets the minimum physical and mechanical requirements laid down in the legislation on gypsum plasters (Spanish and European standard UNE EN 13279 and Spanish specifications for gypsum acceptance, $R Y$ 85). Under this design, a one-metre square, $1.5-\mathrm{cm}$ thick board contains $4.75 \mathrm{~kg}$ of PCM, much more than in any prior drylining (the maximum attained to date is $3 \mathrm{~kg}$ per $\mathrm{m}^{2}$ ). The mechanical and physical characteristics of this new composite were previously improved with two joint-action additives: polypropylene fibres and melamine formaldehyde as a dispersing agent.

In the 20-30 ${ }^{\circ} \mathrm{C}$ temperature range, a gypsum board 1.5 $\mathrm{cm}$ thick containing this percentage of PCMs can store five times more thermal energy than conventional plasterboard of the same thickness, and the same amount of energy as half-foot hollow brick masonry.

Keywords: gypsum, PCM, thermal energy, storage, latent heat, physical properties, mechanical properties.

(*) Universidad Politécnica de Madrid (Madrid, España). 


\section{INTRODUCCIÓN}

Frente al problema de crisis energética mundial que arrastramos desde el siglo pasado y el futuro incierto que nos depara, se está trabajando en las últimas décadas en pro de la reducción del consumo energético y del uso de fuentes de energía renovables. Ligado al uso de energías renovables está el concepto de almacenamiento energético, que permite ajustar los periodos de suministro a los de demanda, garantizando una mayor eficiencia energética.

El almacenamiento térmico ha estado ligado a la arquitectura desde la antigüedad y se ha mantenido en las construcciones vernáculas, donde los cerramientos de gran inercia térmica garantizaban una temperatura prácticamente constante a lo largo del día, lo que significa una gran contribución a la mejora de las condiciones de habitabilidad y confort del espacio habitable y una reducción del uso de sistemas de calefacción y refrigeración.

Existen otras alternativas a este modo de almacenamiento térmico en forma de calor sensible, que son el almacenamiento por reacción termoquímica y el almacenamiento por calor latente.

Esta última es la que está desarrollándose con mayor interés en las últimas décadas ya que garantiza una mayor densidad de almacenamiento térmico, se reducen las pérdidas energéticas (puesto que la capacidad de almacenamiento térmico no está ligada a la variación de temperatura del material acumulador) y la temperatura de trabajo es ajustable a las necesidades de cada aplicación. Esta forma de almacenamiento térmico se realiza con materiales de cambio de fase (PCMs, del acrónimo inglés phase change materials), que acumulan o ceden energía cuando cambian de fase, de estado de hidratación o de ordenación molecular (1).

Son muchas sus aplicaciones en diversos campos (sanitario, botánico...) (2-5). En el campo de la construcción se están realizando diversos trabajos de investigación -desde inicios de los años ochenta- para integrarlos en diferentes elementos constructivos (hormigón, yeso, cerámica, vidrio...) con el fin de mejorar su inercia (6).

Se ha elegido el yeso como material más adecuado para desarrollar un nuevo producto de construcción por su disponibilidad, profusa utilización en el campo de la edificación y bajo coste, entre otras propiedades como la facilidad de integración de nuevos aditivos y, por ende, su buena predisposición para mejorar cualitativamente y tecnificarse, así como la posibilidad de aplicarlo in situ o como elemento prefabricado. Tiene además la ventaja, frente a otros materiales como el hormigón, que cumplen estas características, de que se colocan normalmente en la cara interna de los cerramientos (fachadas), o como elemento separador de estancias. Esto asegura su

\section{INTRODUCTION}

To confront the world-wide energy crisis that began in the last century and the uncertain future it entails, work has been undertaken in the last few decades on ways to reduce energy consumption and draw power from renewable sources. The notion of renewable energy is associated with the use of energy storage, in which energy supply timing is adjusted to demand to enhance energy efficiency.

Thermal storage has been an architectural concern since antiquity, and has been consistently addressed in vernacular construction, where enclosures with great thermal inertia ensure practically constant indoor temperatures all day. In modern construction, this approach constitutes a major contribution to the habitability and comfort of indoor space and a reduction in the use of heating and air conditioning.

Other alternatives to thermal storage in the form of sensible heat include thermal-chemical reaction storage and latent heat.

This second alternative has been the focus of particular attention in the last few decades, for it guarantees denser thermal storage and reduces energy leaks (since the thermal storage capacity is not linked to temperature variations in the storage material). Furthermore, the working temperature can be adjusted to the needs of each application. This type of thermal storage is attained with phase change materials (PCMs), that store or release energy when they change phase, hydration state or molecular arrangement (1).

They are widely used in a number of fields (such as health care or botany) (2-5). In construction, research on PCMs has been ongoing since the early eighties to increase the inertia of construction materials such as concrete, gypsum, fired clay and glass (6).

In the present study, gypsum was chosen as the most suitable material to develop a new construction product on the grounds of its availability, common use in building and low cost, in addition to other properties such as its ready miscibility with new additives and consequently the facility with which it may be qualitatively improved, not to mention its prefabricability and ease of on-site installation. Another advantage, compared to materials such as concrete that also meet these requirements, is that it is normally installed on the inside of enclosures or façades or as partition walls. This ensures its position on the inner side of the insulation, and hence the use of 
posición del lado interior del aislamiento, lo que asegura un aprovechamiento de su capacidad teórica de almacenamiento térmico de un $90-95 \%$ — capacidad térmica útil (7) - frente a un aprovechamiento del $10-15 \%$ de su capacidad teórica de almacenamiento térmico, cuando se coloca al exterior del aislamiento (Figura 1).
$90-95 \%$ of its theoretical thermal storage or heat capacity (7) compared to $10-15 \%$ when it is laid on the outer side (Figure 1).

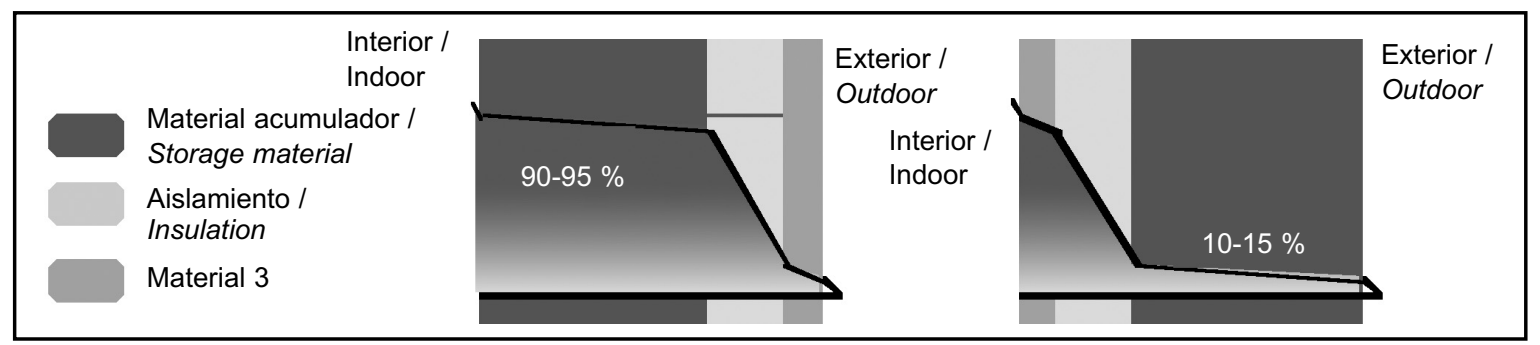

Figura 1. Diferencias en la capacidad de almacenamiento térmico útil de dos cerramientos formados por las mismas capas con diferente orden. A la izquierda el material acumulador se coloca al interior de la hoja de aislamiento y al exterior en el de la derecha (7).

Figure 1. Comparison of heat capacity in two enclosures consisting of the same layers, arranged differently Left, with the storage material on the inner, and right, on the outer side of the insulation (7).

El método utilizado suele ser de forma directa: el PCM líquido o en polvo se añade y se mezcla con el yeso durante su producción.

La incorporación de PCM en materiales de construcción porosos - concretamente el yeso- es objeto de estudio desde los años noventa $(8,9)$.

Feldman D. (10) comprobó en sus experimentos la compatibilidad de los paneles de yeso con gran variedad de PCM, incluyendo ácidos grasos y ésteres. El porcentaje máximo alcanzado en estos ensayos fue de un $25 \%$ en peso de PCM.

Otros investigadores han sido Shapiro (11), que ha recopilado numerosos PCM para introducir en tableros de yeso, para aplicaciones térmicas; Kedl y Stovall (12), que experimentaron con diferentes formas de incorporación de PCM a tableros de yeso; Neeper (13), que incorpora de forma directa butil estearato a paneles convencionales de yeso (21-22\% en peso) junto a agentes dispersantes.

Khudhair y Farid (14) en sus experimentos mostraron que la impregnación se llevaba a cabo simplemente sumergiendo muestras de paneles en PCM fundido durante varios minutos. Dos ejemplos o láminas de tablero $(100 \times 100 \times 10 \mathrm{~mm})$ impregnado con parafina $(23,2 \%$ peso $R T 20)$ y butil estearato $(22 \%$ peso BS) se probaron para conocer su estabilidad física y térmica respecto a un panel de referencia (sin PCM).

Ahmad M. (15), de la Universidad Joseph Fourier de Grenoble, ha estudiado diferentes tipos de tableros incluyendo un PCM, con espesores inferiores a $5 \mathrm{~cm}$.

Otros autores como Stovall y Tomlinson (16), Stetiu y Feustel (17), Athientis A. K. (18), Neeper (13), Heim y
The method used is usually straightforward: the PCM liquid or powder is added to and mixed with the gypsum as it is prepared.

The inclusion of PCMs in porous construction materials, and specifically gypsum, has been under study since the nineteen nineties $(8,9)$.

Feldman (10) provided experimental evidence of the compatibility of drylining with a wide variety of PCMs, including fatty acids and esters. The highest percentage of PCM reached in these trials was $25 \%$ wt.

Other authors include Shapiro (11), who compiled many PCMs for inclusion in plasterboard for thermal use; Kedl and Stovall (12), who experimented with different ways to include PCMs in drylining; and Neeper, (13), who mixed (21-22\% wt) butyl stearate, in conjunction with dispersing agents, with conventional plasterboard directly.

Khudhair and Farid (14) conducted experiments that showed that the material could be impregnated by simply immersing the boards in molten PCM for a few minutes. Two board samples or laminates (100 x $100 \times$ $10 \mathrm{~mm})$, impregnated with paraffin (23.2\% wt of RT20) and butyl stearate (22\% wt BS), were tested for physical and thermal stability and compared to a control board (with no PCM).

Ahmad (15) studied the inclusion of a PCM in different types of boards with thicknesses of under $5 \mathrm{~cm}$.

Other researchers such as Stovall and Tomlinson (16), Stetiu and Feustel (17), Athientis (18), Neeper (13), 
Clarke (5), Darkwa y Kim (19), Ibáñez, Lázaro et al. (20) realizaron investigaciones sobre paneles de yeso con PCM incorporado únicamente desde el punto de vista de almacenamiento energético, donde los porcentajes de PCM incorporado en el panel son del $20-25 \%$ en peso.

Comercialmente existe un producto basado en la incorporación de PCM a paneles de yeso laminado - Smart Board, de BASF (21)-, que incorpora un $26 \%$ en peso del material, es decir, $3 \mathrm{~kg} / \mathrm{m}^{2}$ de panel, con $1,5 \mathrm{~cm}$ de espesor. Esta cantidad es la mayor incorporada hasta el presente trabajo a una placa de yeso.

Hay dos limitaciones en la incorporación de PCM a materiales de construcción como el yeso y el hormigón, que afectan a todos los trabajos anteriores:

- La porosidad del material fraguado en el caso de incorporación por inmersión. El PCM rellena los huecos intersticiales del material. En los estudios realizados hasta la fecha, el máximo porcentaje incorporado a paneles de hormigón ha sido de un $20 \%$ y algo menos en placas de yeso.

- La capacidad mecánica del material, tanto en el caso de incorporación directa como por inmersión. Hasta la fecha, la máxima proporción de PCM incorporada a paneles de hormigón por incorporación directa ha sido de un $23 \%$, pues cantidades superiores limitan sus prestaciones mecánicas. En el caso del yeso, el máximo porcentaje de PCM incorporado ha sido un $26 \%$, por las mismas razones.

Respecto a trabajos con yeso reforzado con adiciones binarias -fibras y dispersión-, existe una línea de investigación iniciada en el Departamento de Construcción y Tecnología Arquitectónica de la ETSAM por A. García Santos, en cuya tesis caracterizaba el comportamiento mecánico del yeso reforzado con polímeros sintéticos (22).

En esta línea se han publicado diversos trabajos sobre comportamiento mecánico de yeso reforzado con polímeros sintéticos (23) dentro del Programa PROFIT 2000.

En este trabajo se ha fabricado un material compuesto cuya matriz es el yeso, con un 44,5\% de PCM incorporado - respecto al peso total del compuesto-, lo que garantiza una mayor capacidad de almacenamiento térmico del nuevo material constructivo. Gracias a la incorporación de elementos de refuerzo, este material cumple además con las recomendaciones dadas por la normativa de aplicación en cuanto a características físicas y mecánicas, lo que garantiza un uso y aplicación propios de yesos.
Heim and Clarke (5), Darkwa and Kim (19), and Ibáñez, Lázaro et al. (20) conducted studies on gypsum boards containing PCM from the energy standpoint only, with PCM contents of $20-25 \% w t$.

One product based on the inclusion of PCMs in laminated drylining is presently marketed, BASF'S SmartBoard (21), which contains $26 \%$ of the material, or $3 \mathrm{~kg} / \mathrm{m}^{2}$ in a $1.5-\mathrm{cm}$ thick board. Prior to the present study, this was the highest percentage included in a gypsum board.

The two factors listed below have limited the inclusion of PCMs in construction materials such as gypsum and concrete in all the studies conducted to date:

- The porosity of the hardened material when the inclusion method involves immersion. The PCM fills the interstitial voids in the material. The highest percentage reported for concrete panels is $20 \%$, and for gypsum board somewhat less.

- The mechanical strength of the material, both in direct and immersion-based inclusion. The highest percentage of PCM included in concrete panels to date is $23 \%$, for higher proportions are detrimental to their mechanical characteristics. For the same reason, the gypsum boards produced to date contain no more than $26 \%$ PCM.

A line of research on gypsum reinforced with joint-action additives (fibres and dispersing agents) is in place at the Madrid School of Architecture's Department of Construction and Architectural Technology. It was initiated by $A$. García Santos, who characterized the mechanical behaviour of synthetic polymer-reinforced gypsum in his 1988 PhD. Thesis (22).

A number of papers have been published on the mechanical behaviour of synthetic-polymer reinforced gypsum as part of the 2000 PROFIT (Spanish initials for Programme for the Furtherance of Technological Research) programme (23).

In the present study, a new gypsum matrix composite material was developed with $44.5 \%$ (wt of the total composite) PCM, guaranteeing higher thermal storage capacity. Thanks to the inclusion of reinforcements, this material meets all the applicable recommendations on physical and mechanical characteristics, making it apt for use in applications typical of conventional gypsum plaster. 


\section{ENSAYOS}

Condiciones de los ensayos: según la EN 13279.2, para una correcta ejecución de los ensayos las condiciones han de cumplir las siguientes especificaciones:

- Temperatura de laboratorio $=20^{\circ} \pm 2{ }^{\circ} \mathrm{C}$.

- Humedad relativa $>65 \%$.

- Los materiales y herramientas para la fabricación de probetas estancas serán impermeables y resistentes al $\mathrm{Ca}_{2} \mathrm{SO}_{4}$.

- Los materiales y herramientas de realización de ensayos estarán limpios.

Materiales utilizados:

- Matriz: escayola E.30.L, "La Maruxiña". Dosificación: sacos de $30 \mathrm{~kg}$.

- Fibras: polipropileno (25 mm y 7 deniers), "Propilan". Dosificación: Sacos de $15 \mathrm{~kg}$.

- Dispersión: policondensado de melamina-formaldehído, "Bettor", Melment L-10. Dosificación: recipiente de $20 \mathrm{I}$.

- Material de cambio de fase: Micronal DS 5001X. Dosificación: sacos de $15 \mathrm{~kg}$.

\section{TESTS}

Test conditions: European standard EN 13279.2 lays down the following specifications for these tests:

- Laboratory temperature $=20^{\circ} \pm 2^{\circ} \mathrm{C}$.

- Relative humidity > 65\%.

- Use of waterproof, $\mathrm{Ca}_{2} \mathrm{SO}_{4}$-resistant materials and tools to prepare water-tight specimens.

- Use of clean materials and tools throughout the tests.

Materials:

- Matrix: "La Maruxiña" E.30.L plaster in 30-kg bags.

- Fibre: "Propilan" (25-mm and 7-denier) polypropylene in 15-kg bags.

- Dispersing agent: Bettor "Melment L-10" melamineformaldehyde polycondensate in 20-I vats

- Phase change material: Micronal DS 5001X in 15-kg bags.

\section{PHYSICAL TEST RESULTS}

\section{ANÁLISIS DE RESULTADOS DE LOS ENSAYOS FÍSICOS CON PROBETAS}

Tabla 1 / Table 1

Ejemplo de nomenclatura de las probetas. Example of specimen nomenclature.

\begin{tabular}{|c|c|c|c|c|}
\hline & Abreviaturas / Abbreviation & & $\begin{array}{l}\text { Letras griegas I } \\
\text { Greek letter }\end{array}$ & \\
\hline $\mathrm{A}$ & Agua / Water & $\rho$ & Densidad / Density & {$\left[\mathrm{Kg} / \mathrm{m}^{3}\right]$} \\
\hline D & $\begin{array}{c}\text { Dispersión (Melamina Formaldehído) / } \\
\text { Dispersing agent (melamine-formaldehyde) }\end{array}$ & & Unidades / Unit & \\
\hline $\mathrm{F}$ & Fibra (polipropileno) / Fibre (polypropylene) & $\mathrm{L}$ & Longitud & [m] \\
\hline G & Gel, material de cambio de fase / Gel, phase change material & $\mathrm{m}$ & Masa & [kg] \\
\hline PCM & Material de cambio de fase / Phase change material & $\mathrm{q}$ & carga & $\mathrm{kN}$ \\
\hline PR & Probeta / Specimen & $\mathrm{t}$ & Tiempo & [s] \\
\hline $\mathrm{Y}$ & Yeso / Gypsum & & & \\
\hline
\end{tabular}

La probeta denominada 100Y-90A-4F-5D-80G posee $100 \%$ de yeso, $90 \%$ de agua, $4 \%$ de fibra, $5 \%$ de dispersión y $80 \%$ de PCM, en proporciones relativas a la cantidad de yeso, que se toma como $100 \%$.

Así para hacer esta muestra, si ponemos por ejemplo $1.000 \mathrm{~g}$ de yeso, necesitaríamos $900 \mathrm{~g}$ de agua, $40 \mathrm{~g}$ de fibra, $50 \mathrm{~g}$ de dispersión y $800 \mathrm{~g}$ de PCM.

\subsection{Reducción de peso}

Es la sufrida tras el proceso de fraguado y secado de la pasta la por pérdida de agua de la mezcla.
The specimen denominated 100Y-90A-4F-5D-80G contains $100 \%$ gypsum, $90 \%$ water, $4 \%$ fibre, $5 \%$ dispersing agent and $80 \%$ PCM, all relative to the amount of gypsum, which is taken to be $100 \%$.

A sample with these proportions containing $1000 \mathrm{~g}$ of gypsum, then, would also contain $900 \mathrm{~g}$ of water, $40 \mathrm{~g}$ of fibre, $50 \mathrm{~g}$ of dispersing agent and $800 \mathrm{~g}$ of PCM.

\subsection{Weight loss}

This parameter refers to the weight of the water lost during paste setting and drying. 
Las gráficas obtenidas de los ensayos son casi lineales (Figura 2), ya que el factor más determinante en cuanto a la reducción de peso se refiere son:

- La relación agua/yeso: está en relación directa con la pérdida en peso que experimenta la pasta, siendo mayor cuanta mayor sea la relación $A / Y$. En efecto, cuanto más cantidad de agua se añada a la mezcla, más cantidad de agua tiene habrá que perder ya que -químicamente expresado- por cada molécula de semihidrato CaSO4+ $1 / 2 \mathrm{H}_{2} \mathrm{O}$ se necesitan $3 / 2$ de $1 / 2 \mathrm{H}_{2} \mathrm{O}$, para formar el dihidrato.

- El aumento de la proporción de PCM: disminuye sensiblemente la pérdida en peso (\%). El PCM se presenta como un microencapsulado con un diámetro de 2-20 micrómetros, es decir, como un agregado muy fino, lo que implica mayor cantidad de discontinuidades en la masa del compuesto.

Así, para un porcentaje de agua del $70 \%$, la reducción de peso varía del $32 \%$ (sin PCM) al $24 \%$ (con el $80 \%$ de PCM); cuando el porcentaje de agua es del $80 \%$, la reducción varía del 35,2\% (con $0 \%$ de $\mathrm{PCM}$ ) al 25,7\% (para $80 \%$ de PCM); mientras que para la mezcla con $90 \%$ de agua, los valores oscilan entre $39 \%$ y $26 \%$.

Respecto a la influencia de los otros componentes se puede decir:

- La incorporación de fibras no afecta de manera significativa a la reducción de peso.

- La adición de dispersión (melamina) contribuye a la disminución en la reducción de peso en tanto y cuanto reduce las necesidades de agua en la mezcla.

- Para una misma cantidad de agua y de PCM no están claros los efectos que produce la adición de dispersión en cuanto a la reducción de peso, ya que varía con las distintas proporciones de los diferentes agregados en la mezcla.
The graphs obtained in the trials were nearly linear (Figure 2), for the following two factors are determinants in weight loss:

- The water/gypsum $(A / Y)$ ratio is directly related to paste weight loss; the higher the ratio, the greater the loss. Indeed, the more water that is added to the mix, the more that will have to evaporate, since chemically speaking, for every molecule of $\mathrm{CaSO}_{4}+$ 1/2 $\mathrm{H}_{2} \mathrm{O}$ semihydrate present, $3 / 2$ of $1 / 2 \mathrm{H}_{2} \mathrm{O}$ are needed to form the dihydrate.

- The increase in the percentage of PCM reduces weight loss appreciably (\%). The PCM adopts the form of a microcapsule 2-20 micrometers in diameter: i.e., as a very fine powder it generates numerous discontinuities in the composite matrix.

For pastes with $70 \%$ water, the weight loss varies from $32 \%$ (no PCM) to $24 \%$ ( $80 \%$ PCM). When the water content is $80 \%$, weight loss ranges from $35.2 \%(0 \%$ PCM) to $25.7 \%$ (80\% PCM). And for $90 \%$ water, these values range from 30 to $26 \%$.

The effect of the other components is summarized below:

- The inclusion of fibres has no significant effect on weight loss.

- The addition of dispersing agents (melamine) contributes to reducing weight loss, as much as it lowers the water demand.

- For a given amount of water and PCM, the effect of adding a dispersing agent on weight loss is unclear, for it varies depending on the proportions of the mix constituents.

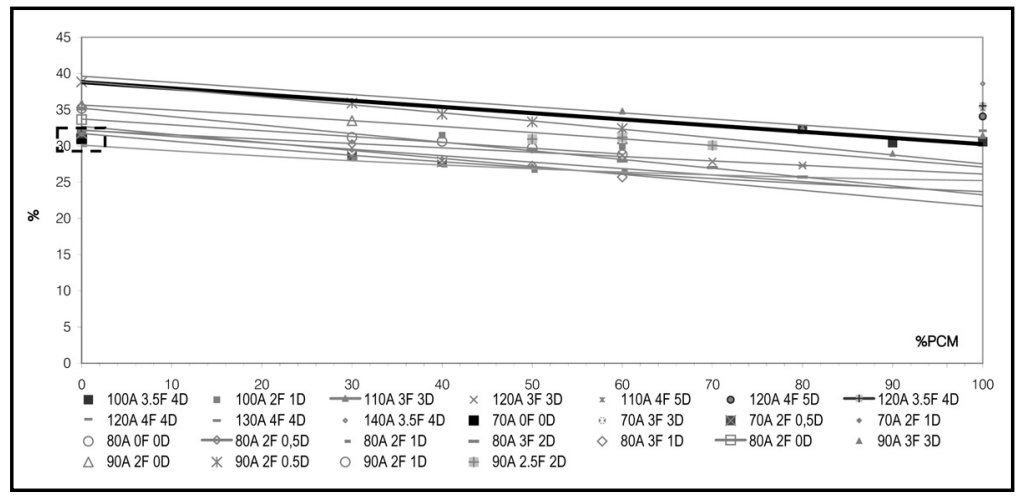

Figura 2. Reducción de peso: resultados obtenidos en las diferentes dosis. Se recuadra el valor de la probeta base $(A / Y, 0,7)$ y se marca la línea de tendencia de la dosis elegida.

Figure 2. Weight loss: findings with different dosages. The reference specimen $(A / Y=0.7)$ and minimum recommended value is framed and the trendline of the selected dosage is emphasized. 


\subsection{Densidad}

Las densidades obtenidas en la muestra patrón —sin adiciones - son del orden de $1,12 \mathrm{~g} / \mathrm{cm}^{3}$ y se halla en el rango establecido por la normativa (Figura 3 ).

La línea de tendencia derivada de los resultados obtenidos es polinómica, de lo que se deduce que todos los agregados influyen en aquellos.

Según esto se pueden determinar las siguientes conclusiones:

- Una mayor proporción de agua en la mezcla aumenta la densidad húmeda y disminuye la densidad seca, tanta más cuanta mayor cantidad de microencapsulado se incorpore.

- Así, para las muestras que no contienen PCM, el valor es similar tanto para las probetas con $70 \%$, como las de 80,90 o $100 \%$ de agua $(0,85-0,9 \mathrm{~g} / \mathrm{cm} 3)$. Para dosis de $80 \%$ de Micronal, este valor es de 0,8-0,82 $\mathrm{g} / \mathrm{cm}^{3}$ en las probetas con $70 \%$ de agua; $0,77 \mathrm{~g} / \mathrm{cm}^{3}$ para las de $80 \%$; próximas a $0,75 \mathrm{~g} / \mathrm{cm}^{3}$ para las de $90 \%$, y 0,7 y $0,65 \mathrm{~g} / \mathrm{cm}^{3}$ para las de $100 \%$ y $130 \%$ de agua respectivamente.

- La incorporación de dispersión aumenta la densidad seca de las muestras, ya que disminuye la avidez de agua.

- El incremento de la proporción de fibras disminuye la densidad húmeda y seca de la muestra ya que incrementa el volumen sin apenas añadir masa.

- El aumento del porcentaje de PCM reduce tanto la densidad húmeda como la seca de la mezcla. Ello se explica porque la densidad de éste es inferior a la del yeso, $2,3-2,5 \mathrm{~g} / \mathrm{cm}^{3}$ frente a $6,5-11 \mathrm{~g} / \mathrm{cm}^{3}$ del polvo de yeso. Así, para muestras con $0 \%$ de PCM, la densidad seca oscila entre $0,85-0,9 \mathrm{~g} / \mathrm{cm} 3$, mientras que para $80 \%$ de PCM ésta cae hasta un $0,77 \mathrm{~g} / \mathrm{cm}^{3}$.

\subsection{Density}

The density values found in the (additive-free) control sample were on the order of $1.12 \mathrm{~g} / \mathrm{cm}^{3}$, which falls in the recommended range (Figure 3 ).

The curves plotted from the data found were polynomial, an indication that all the constituents contributed to those findings.

The conclusions that may be drawn from the foregoing are as follows:

- $\quad$ A higher proportion of water in the mix raised the wet and lowered the dry density, more intensely when more PCM microcapsules were added.

- For samples with no PCM, density $\left(0.85-0.9 \mathrm{~g} / \mathrm{cm}^{3}\right)$ was similar regardless of water content $(70,80,90$ or $100 \%$ ). With $80 \%$ Micronal, density was $0.8-0.82$ $\mathrm{g} / \mathrm{cm}^{3}$ in specimens with $70 \%$ water, $0.77 \mathrm{~g} / \mathrm{cm}^{3}$ in specimens with $80 \%$, around $0.85 \mathrm{~g} / \mathrm{cm}^{3}$ in specimens with $90 \%$ and 0.7 and $0.65 \mathrm{~g} / \mathrm{cm}^{3}$ in specimens with 100 and $130 \%$ water, respectively.

- The inclusion of a dispersing agent raised the dry density of the samples, for it lowered the water demand.

- Rising percentages of fibre lowered wet and dry density both, for they raised the volume significantly with barely any additional mass.

- Higher percentages of PCM reduced both the wet and dry mix density. The reason is that the phase change material is less dense than gypsum: $2.3-2.5 \mathrm{~g} / \mathrm{cm}^{3}$ compared to $6.5-11 \mathrm{~g} / \mathrm{cm}^{3}$ for gypsum powder. For samples with $0 \%$ PCM, the dry density ranged from 0.85 to $0.9 \mathrm{~g} / \mathrm{cm}^{3}$, while for specimens with an $80 \%$ $P C M$ content, density fell to $0.77 \mathrm{~g} / \mathrm{cm}^{3}$.

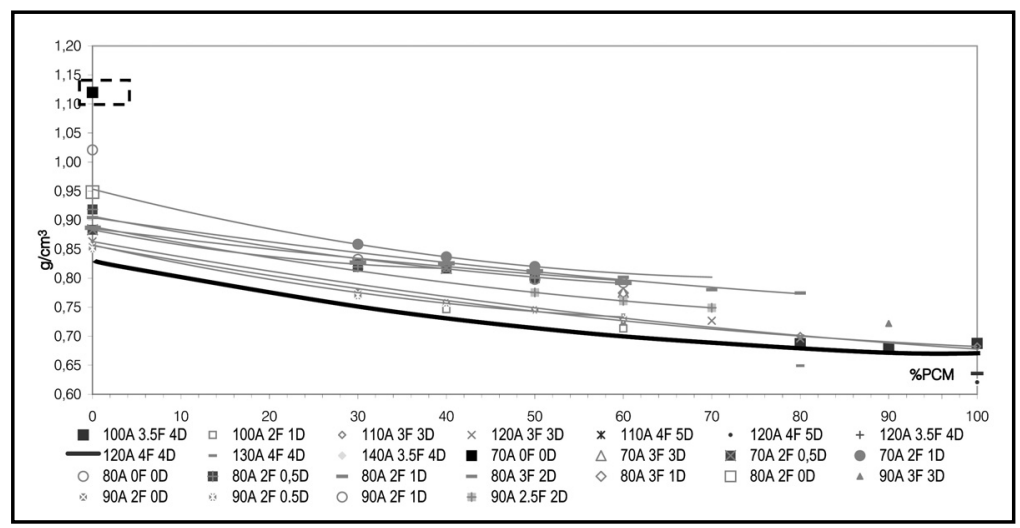

Figura 3. Densidad seca: resultados obtenidos en las diferentes dosis. Se recuadra el valor de la probeta base $(A / Y, 0,7)$ y se marca la línea de tendencia de la dosis elegida.

Figure 3. Dry density: values at different dosages. The reference specimen $(A / Y=0.7)$ and minimum recommende value is framed and the trendline of the selected dosage is emphasized. 


\subsection{Tiempo de fraguado}

Es el tiempo que tarda la pasta de yeso fresca en perder su trabajabilidad y comenzar su endurecimiento.

- Una mayor finura del yeso favorece también una evolución rápida de sus propiedades, en particular de su fraguado, ya que hay más superficie de contacto, que incrementa la atracción entre estas partículas y el agua.

- La adición de fibras disminuye considerablemente el tiempo de fraguado, reduciendo el efecto de aumento que podría suponer el agua y la dispersión. Este aspecto se estudia en profundidad en la tesis doctoral de García-Santos (22), donde se elaboraron 900 muestras de material para analizar la influencia de diferentes adiciones a la matriz de escayola, en el comportamiento físico y mecánico del compuesto.

- La adición de PCM influye en el tiempo de fraguado en tanto que aportan materia seca al conjunto, por lo que incrementan la avidez de agua de los diferentes agregados.

En este tipo de mezclas, con escasa proporción de agua, se ha utilizado una elevada cantidad de dispersión (5\%) para retardar el tiempo de fraguado. Se ha observado durante el amasado de éstas el efecto fluidificante que posee la melamina, multiplicando los efectos del agua a los pocos segundos de iniciarse la reacción, lo que ha posibilitado cierta trabajabilidad del material.

Aun así, es necesario asegurar una cierta cantidad de agua en relación a la suma total de la materia seca -esto es, escayola, PCM y fibras- para que la dispersión tenga efecto fluidificante.

Para aumentar el tiempo de fraguado, de cara a una aplicación comercial del producto, sería recomendable utilizar unas dosis más elevadas de dispersión, evitando utilizar más cantidad de agua, que reduce las propiedades mecánicas, como se verá más adelante.

\subsection{Trabajabilidad de la muestra}

La trabajabilidad de la mezcla con fibras es inferior a la del yeso convencional. Ello se debe a que las fibras, delgadas y alargadas, con geometría muy diferente a la del resto de los agregados - yeso y microencapsulados de PCM-, pudiendo provocar una trabazón que dificulta la mezcla, al tiempo que su gran superficie específica absorbe agua libre, lo que resta fluidez a la mezcla. Cuanto mayor es la proporción de fibras y su coeficiente de aspecto, menor es la trabajabilidad de la mezcla.

Se requiere una mayor energía de compactación al ser mayor la consistencia (según ensayos realizados).

\subsection{Setting time}

This is the time it takes the fresh plaster to cease to be workable and begin to harden:

- The finer the gypsum powder used, the sooner the paste properties developed, especially setting, for the larger contact area enhanced the attraction between the particles and the water.

- Adding fibres reduced setting time considerably and mitigated the retardation that might be induced by the water and the dispersing agent. This issue was addressed in depth by García-Santos in his PhD. thesis (22), for which 900 specimens were prepared to analyze the effect of including different additives in the plaster matrix on the physical and mechanical behaviour of the composite.

- The addition of PCMs affected setting time insofar as it raised the amount of dry matter to the mix, thereby increasing the water demand.

In this type of mixes with a low water content, high proportions (5\%) of dispersing agent were used to retard the setting time. The fluidising effect of melamine was observed as the mixes were prepared: it reinforced the effect of the water just seconds after the reaction began, affording the material some degree of workability.

Nonetheless, a certain minimum amount of water with respect to the sum of all the dry matter (gypsum, PCM and fibre) was found to be needed for the dispersing agent to be effective.

With a view to commercial use of the product, higher doses of dispersing agent would be required to raise the setting time without resorting to the addition of more water, which has an adverse effect on mechanical properties, as discussed below.

\subsection{Sample workability}

Fibre-containing pastes proved to be less workable than conventional plaster. This was because the geometry of long, thin fibres, which differs radically from the shape of the other components (gypsum and PCM microcapsules), may have induced lumping that would hinder mixing. At the same time, their large specific surface absorbed the free water, to the detriment of mix flowability. The higher the proportion of fibres and their aspect ratio, the lower was mix workability.

Greater compaction energy was needed because of the greater consistency (according to the tests conducted). 
La trabajabilidad disminuye con la adición de PCM, ya que incrementa la proporción de masa seca respecto a la cantidad de agua.

La incorporación de dispersión mejora la trabajabilidad de la muestra para la misma proporción de agua, pudiendo reducirse hasta un $10 \%$ de agua por $1 \%$ de dispersión añadida.

\section{ANÁLISIS DE RESULTADOS DE LOS ENSAYOS MECÁNICOS CON PROBETAS}

\subsection{Dureza Shore C}

Las gráficas de dureza Shore C (Figura 4) tienen forma parabólica con una pendiente más acusada en el primer tramo, que va suavizándose paulatinamente hasta llegar a ser 0 prácticamente a dosis de PCM superiores al $80 \%$.

Esta cierta complejidad en la formulación del comportamiento de las muestras en lo que a dureza Shore $C$ se refiere es debida a la participación de varios agentes -las distintas adiciones de la mezcla- y a las diferentes relaciones intrínsecas que se producen entre ellos en las distintas dosificaciones de las muestras. Así se puede decir que el aumento de la cantidad de PCM disminuye de la dureza superficial del compuesto.

Para la serie $100 \mathrm{Y}-70 \mathrm{~A}-2 \mathrm{~F}-0,5 \mathrm{D}$, la dureza Shore $\mathrm{C}$ inicial - con $0 \%$ de PCM- es de 73,3 ud, que correspondería al $100 \%$ de su resistencia. Con el $30 \%$ de PCM disminuye ligeramente hasta un $75,76 \%$, con el $40 \%$ baja hasta el $71,7 \%$.

Para la serie $100 \mathrm{Y}-70 \mathrm{~A}-2 \mathrm{~F}-1 \mathrm{D}$, la dureza Shore C inicial - con $0 \%$ de PCM- es de 68 ud. Con el $30 \%$ de PCM disminuye ligeramente hasta un $80,05 \%$, con el $50 \%$ baja hasta el 71,07\%.

En la serie $100 \mathrm{Y}-100 \mathrm{~A}-3,5 \mathrm{~F}-4 \mathrm{D}$, la dureza Shore C inicial - con $0 \%$ de PCM- es de 80 ud. Con el $80 \%$ de PCM disminuye ligeramente hasta un $73,78 \%$, con el $100 \%$ baja hasta el $72,43 \%$ :

- La adición de fibra y dispersión a la mezcla mejora la dureza superficial del conjunto.

- La mayor proporción de fibra y dispersión en la mezcla, suaviza la reducción del valor de dureza Shore C, que se produce con el aumento de proporción de PCM.

- La mayor proporción de agua disminuye la dureza superficial.

- Este es el caso de la mezcla 100Y-xA-2F-0,5D-0G, en la que para una relación $A / Y=0,7(x=0,7)$, su dureza Shore C es de 72,3 ud, o la 100Y-xA-2F-1D-30G,
Workabilty declined with PCMs, which raised the proportion of the dry mass with respect to the amount of water.

The inclusion of a dispersing agent improved sample workability for a given proportion of water. For every $1 \%$ of dispersing agent added, the water content could be reduced by $10 \%$.

\section{MECHANICAL TEST RESULTS}

\subsection{Shore C hardness}

The Shore $C$ hardness curves were parabolic, with a steeper slope in the first arm, which gradually flattened to nearly zero as PCM dosages rose to $80 \%$ or over (Figure 4).

This relative complexity in the Shore $C$ behaviour of the samples was due to the action of the components and their intrinsic inter-relationships at different sample dosages. It was nonetheless observed that increasing the amount of PCM lowered the surface hardness of the composite.

For the 100Y-70A-2F-0.5D series, for instance, the initial (0\% PCM) Shore $C$ hardness was 73.3 units, which was regarded to constitute $100 \%$ of its strength. With $30 \%$ PCM, the value declined slightly to $75.76 \%$, and with $40 \%$ to $71.7 \%$.

For the 100Y-70A-2F-1D series, the initial (0\% PCM) Shore $C$ hardness was 68 units. With $30 \%$ PCM, the value declined slightly to $80.05 \%$, and with $50 \%$ PCM to $71.07 \%$

For the $100 \mathrm{Y}-100 \mathrm{~A}-3.5 \mathrm{~F}-4 \mathrm{D}$ series, the initial (0\% PCM) Shore $C$ hardness was 80 units. With $80 \%$ PCM, it declined slightly to $73.78 \%$, and with $100 \%$ PCM to 72.43\%:

- The addition of fibre and the dispersing agent improved the overall surface hardness.

- The greater proportion of fibre and dispersing agent in the mix mitigated the decline in Shore $C$ hardness induced by a rise in the proportion of PCM.

- Larger proportions of water reduced surface hardness.

- For instance, in mix 100Y-XA-2F-0.5D-0G, for a water/ gypsum ratio of $0.7(x=0,7)$, the Shore $C$ hardness was 72.23 units, and in mix 100Y- $x A-2 F-1 D-30 G$, for 
en la que para un $70 \%$ de agua se obtienen valores de 59,67 ud, ligeramente superiores a las que contienen un $80 \%$, y éstas a su vez superiores a las que cuentan con un $90 \%$ de agua. De ello se puede obtener la siguiente conclusión. La norma UNE 102-039 "Yesos y escayolas de construcción" establece que la dureza Shore C, para una muestra de yeso sin adiciones, debería ser superior a 45 ud dependiendo de la densidad del yeso, debiendo ser ésta superior cuanto más denso sea aquel.

Así, podemos decir que los valores obtenidos con las adiciones binarias, incluso con la incorporación de cantidades elevadas de PCM (80-100\%), están por encima de los resultados exigidos por la normativa. Muestra de ello son las 52,78 ud de dureza Shore $C$ obtenida en la muestra 100Y-80A-2F-1D-80G, o 56,11 ud en la mezcla 100A-3.5F-4D-100G, con un $100 \%$ de PCM.
$70 \%$ water, values of 59.67 units were obtained. This was slightly higher than found for the samples with $80 \%$ water, which in turn exhibited higher values than the pastes containing $90 \%$ water. The above considerations lead to the following conclusion. Spanish standard UNE 102-039, "Yesos y escayolas de construcción" (Gypsum and plaster for use in construction) provides that the Shore $C$ hardness for a plaster sample containing no additives must be greater than 45 units, and increase with plaster density.

Consequently, the values obtained for the samples containing joint-action additives, even with a PCM content of $80-100 \%$, were higher than required by the legislation. Proof of this lies in the 52.78 Shore $C$ hardness units observed for sample 100Y-80A-2F-1D-80G, or the 56.11 units for mix 100A-3.5F-4D-100G, which contained $100 \%$ PCM.

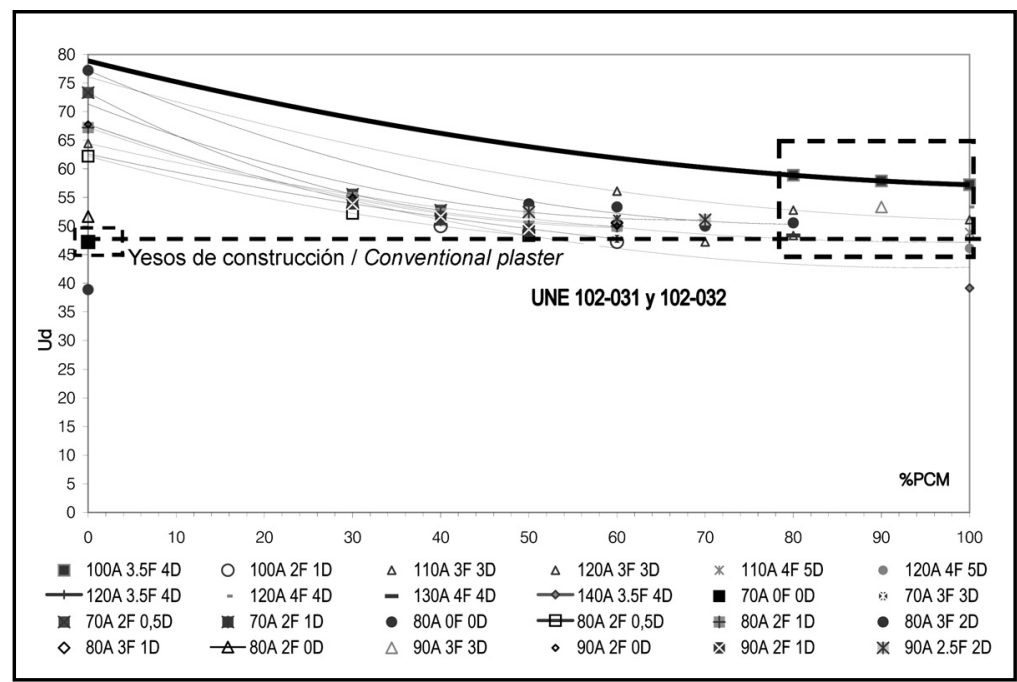

Figura 4. Dureza Shore C: resultados obtenidos en las diferentes dosis. Se recuadra el valor de la probeta base $(A / Y, 0,7)$ y valores mínimos recomendados en la normativa de aplicación y se marca la línea de tendencia de la dosis elegida.

Figure 4. Shore $C$ hardness: findings with different dosages. The reference specimen $(A / Y=0.7)$ and minimum recommended value is framed and the trendline of the selected dosage is emphasized.

\subsection{Resistencia a flexión}

En los resultados obtenidos en los ensayos para la muestra patrón se ha alcanzado un valor medio de 4,78 $\mathrm{MPa}$ superior al valor mínimo recomendado por la Norma EN 13279, que establece $1 \mathrm{MPa}$ para los yesos de construcción y $3 \mathrm{MPa}$ para los yesos con fibras.

Las muestras que incorporan fibra en un $2 \%$ y dispersión en un $0,5 \%$, como las de la Tabla 2 , mejoran hasta 1,5 veces los resultados, debido al trabajo de las fibras y de la dispersión, así como una reducción paulatina en relación a la cantidad de agua aportada.

\subsection{Flexural Strength}

The mean value found for the control sample was 4.78 MPa, which is higher than the $1 \mathrm{MPa}$ minimum recommended for construction plaster and $3 \mathrm{MPa}$ for fibre-reinforced plaster in European standard EN 13279.

As the Table 2 shows, the addition of $2 \%$ fibre and $0.5 \%$ dispersing agent led to a 1.5-fold increase in strength and a gradual reduction in the amount of water. 
Tabla 2 / Table 2

Comparativa de la resistencia a flexión para diferentes compuestos fabricados.

Comparison of bending strength for different compounds produced.

\begin{tabular}{|c|c|c|c|c|c|}
\hline $\mathbf{Y} \%$ & $\mathbf{A} \%$ & $\mathbf{F} \%$ & $\mathbf{D} \%$ & $\mathbf{G} \%$ & $\boldsymbol{\sigma}$ flexión / $\boldsymbol{\sigma}$ bending $\mathbf{M P a}$ \\
\hline 100 & 70 & 0 & 0 & 0 & 4.95 \\
\hline 100 & 70 & 2 & 0.5 & 0 & 7.27 \\
\hline 100 & 80 & 2 & 0.5 & 0 & 6.40 \\
\hline 100 & 90 & 2 & 0.5 & 0 & 5.75 \\
\hline
\end{tabular}

Se puede enunciar así unas líneas generales de comportamiento:

- Las fibras mejoran considerablemente el comportamiento físico-mecánico de la matriz.

- La dispersión -fluidificante- mejora el comportamiento del conjunto.

Esto coincide con lo aportado en investigaciones anteriores (23) y se debe en primer lugar a que:

- La matriz mantiene unidas las fibras, protege su superficie durante la fabricación y manipulación del compuesto y transmite el esfuerzo a las fibras por adherencia o fricción.

- Se produce una adherencia mutua entre los diferentes elementos del compuesto gracias a las fuerzas electrostáticas que se generan entre la estructura cristalina de los diversos componentes de la escayola y la estructura molecular de las fibras de polipropileno, así como por la relación física de tamaños entre la fibra y la estructura cristalina de la escayola hidratada.

- Se produce una deformación armónica bajo carga, relacionada con los sistemas estructurales de absorción de energía, con la adherencia mutua entre componentes del material reforzado, con el acoplamiento de cristales de la escayola, con la deformación de los cristales de la escayola y con la deformación intrínseca de las fibras de polipropileno.

El segundo punto se explica por un aumento de la cohesión intercristalina, es decir:

- Se modifica la estructura de la escayola y su comportamiento intrínseco, al actuar estas fuerzas electrostáticas desde el inicio del proceso de hidratación de los componentes de la escayola y durante el crecimiento cristalino.

- Aumenta la superficie de contacto de los agregados cristalinos de la escayola al disminuir la porosidad interna - las fibras y la dispersión rellenan los huecos intersticiales entre las partículas de escayola-, lo que eleva las resistencias mecánicas.

Para mejorar las prestaciones mecánicas ha sido necesario un trabajo previo de activación de las fibras para mejorar la adherencia electrostática del resto de los
Composite behaviour can be summarized as set out below:

- The fibres improved the physical-mechanical performance of the matrix appreciably.

- The dispersing agent improved overall performance.

These data concurred with prior findings (23) and were attributed primarily to three developments:

- The matrix kept the fibres together, protected their surface during composite manufacture and handling and transferred the stress to the fibres by bonding or friction.

- The constituents bonded together as a result of the electrostatic forces generated between the crystalline structure of the gypsum components and the molecular structure of the polypropylene fibres, as well as of the physical relationship between the size of the fibres and the crystalline structure of the hydrated plaster.

- The harmonic deformation generated when the board was loaded was related to: the energyabsorbing structural systems; bonding among the components of the reinforced material; bonding among the crystals in the plaster; deformation of the plaster crystals; and the intrinsic deformation of the polypropylene fibres.

The second point was the result of an increase in intercrystalline cohesion:

- On the one hand, the plaster structure and its intrinsic behaviour were modified in response to these electrostatic forces, which appeared from the earliest stages of hydration of the plaster components and throughout crystal growth.

- On the other, the contact area of the crystalline components of the plaster rose as internal porosity declined (the fibres and dispersing agent filled the interstitial voids between plaster particles), raising mechanical strength.

Improvement of the mechanical properties called for prior activation of the fibres to enhance their electrostatic bonding to the rest of the elements. 
elementos, así como un proceso de amasado y mezcla de los diferentes materiales del compuesto en aras de conseguir una distribución adecuada de los agregados fibrosos y garantizar una especialización de la absorción de tensiones internas: tracción para las fibras y compresión para el agregado cristalino de la escayola.

Si se observan las gráficas y las líneas de tendencia (Figura 5), se puede apreciar su carácter parabólico, que muestra al principio un rápido descenso -al entrar los PCM en el juego- para suavizar esta tendencia, estabilizando su resistencia a flexión a partir de un porcentaje de PCM, que varía en función de las proporciones del resto de los agregados.

El aumento de la cantidad de PCM supone una disminución de la resistencia a compresión.

Se puede observar que las series que contienen más cantidad de fibra tienen un comportamiento más lineal, es decir, no existe un tramo inicial en el que la inclusión de PCM en el conjunto baje significativamente los valores de resistencia a flexión. Ello se debe a la adherencia mutua que se produce en éstas y los diferentes elementos del compuesto así como por la relación física de tamaños entre la fibra $-25 \mathrm{~mm}-$ y la estructura cristalina del compuesto, contrarrestando el efecto de los PCM.

Para cantidades de PCM de $80 \%$, se obtienen unos valores próximos a $3 \mathrm{MPa}$, gracias a la adición de fibras y dispersión hasta en un $4 \%$ y un $5 \%$ respectivamente, como se observa en la Tabla 3.
Thorough mixing of the materials forming the composite was likewise required to ensure satisfactory distribution of the fibrous components and guarantee discrete absorption of the internal stresses: tensile stress by the fibres and compressive stress by the crystalline components of the plaster.

The curves tended to be parabolic (Figure 5). A steep initial decline (when the PCMs came into play) subsequently eased until bending strength steadied at a given PCM percentage, which varied depending on the proportions of the rest of the components.

Raising the amount of PCMs lowered bending strength.

The series with high fibre contents exhibited more linear behaviour, with no initial arm indicating a significant decline in bending strength as a result of the inclusion of PCMs. This was due to the bonding between the fibres and the other composite elements, and the physical relationship between the fibre size $(25 \mathrm{~mm})$ and the crystalline structure of the composite, which countered the effect of the PCMs.

Values of nearly $3 \mathrm{MPa}$ were obtained for pastes with $80 \%$ PCM, thanks to the addition of $4 \%$ fibres and $5 \%$ dispersing agents, as shown in the following comparative Table 3.

Tabla 3 / Table 3

Comparativa de la resistencia a flexión para diferentes compuestos fabricados con materiales de cambio de fase. Comparison of bending strength for different compounds produced with PCMs.

\begin{tabular}{|c|c|c|c|c|c|}
\hline $\mathbf{Y} \%$ & A \% & F \% & D \% & G \% & o flexión / obending MPa \\
\hline 100 & 90 & 3.5 & 4 & 80 & 2.64 \\
\hline 100 & 90 & 4 & 5 & 80 & 2.5 \\
\hline
\end{tabular}

Con todo ello, se puede afirmar que las muestras realizadas durante la fase experimental (incluso las que contienen un $100 \%$ de PCM) superan la capacidad de resistencia a flexión de los valores, que según la UNE EN 13279, que establece $1 \mathrm{MPa}$ para los yesos de construcción. Se podrían utilizar dosificaciones con hasta un $80 \%$ de PCM para realizar trabajos de yeso con fibras.

Para conocer con precisión como influyen por separado cada una de las adiciones sería necesario realizar más probetas, en las que participase cada una por separado con la escayola, y otras con adiciones dos a dos, para ver cómo interactúan entre sí en conjunto e individualmente. Con ello se obtendría un análisis del comportamiento tensión- deformación- plastificación-rotura del compuesto en aras de optimizar las cantidades de cada agregado.
Further to the foregoing, all the samples prepared during the experimental phase (including the pastes with $100 \%$ $P C M)$ exhibited higher bending strength than required in Spanish and European standard UNE EN 13279, which specifies a value of $1 \mathrm{MPa}$ for gypsum plaster used in construction. Dosages containing up to $80 \%$ PCM may consequently be used in fibre-reinforced plaster.

A more precise understanding of the effect of each additive separately would call for the preparation of more specimens, some containing each additive separately and others the two combined, to determine how they interact individually and jointly. This could be used to conduct a stress-strain-plasticization-failure analysis of the composite with which to optimize the amounts of each component. 


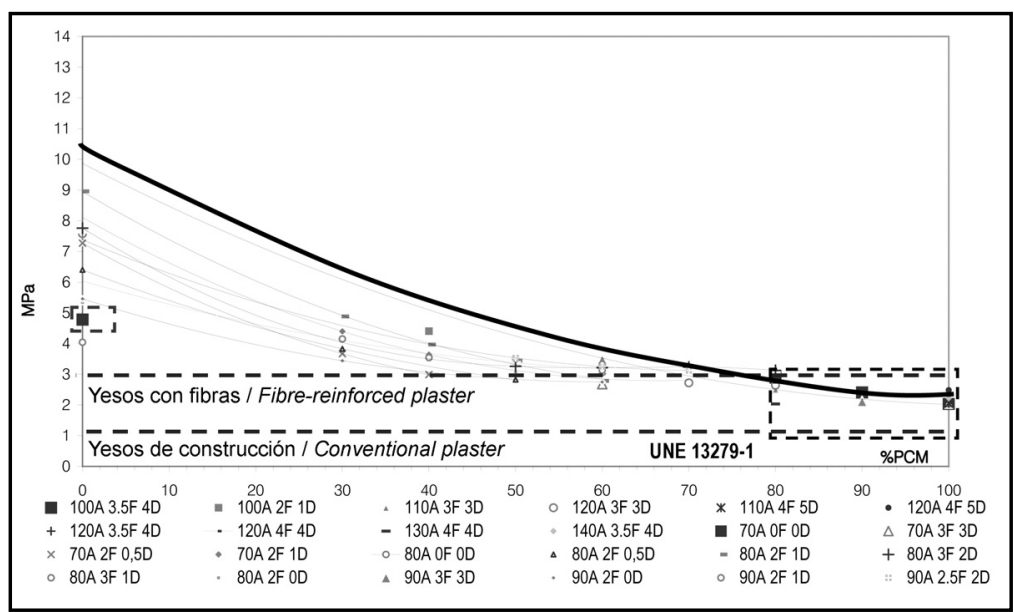

Figura 5. Resistencia a flexión: resultados obtenidos en las diferentes dosis. Se recuadra el valor de la probeta base $(A / Y, 0,7)$ y valores mínimos recomendados en la normativa de aplicación y se marca la línea de tendencia de la dosis elegida.

Figure 5. Bending strength: findings with different dosages. The reference specimen $(A / Y=0.7)$ and minimum recommended value is framed and the trendline of the selected dosage is emphasized.

Para el ensayo de placas se ha considerado más interesante seguir las instrucciones del Pliego de Recepción de Yesos que -aunque está derogado- es el único que fija para la escayola tipo E-30 - material con el que he trabajado en el laboratorio- una resistencia mínima a flexión y es referencia de muchos trabajos de investigación en este campo.

Sería posible fabricar industrialmente placas de yeso laminado, en cuyo caso la normativa de aplicación sería la UNE 520 —en vigor desde marzo de 2007-que recomienda para las placas de yeso laminado del tipo A-D-E-F-H-I, con un espesor nominal de 9,5 mm, una carga de rotura en sentido transversal de $160 \mathrm{~N}$ y $400 \mathrm{~N}$ en sentido longitudinal. Para las del tipo $\mathrm{R}$ (de resistencia mejorada), 300 y $725 \mathrm{~N}$ respectivamente, y $125 \mathrm{~N}-180 \mathrm{~N}$ para las del tipo P (placa base de yeso).

\subsection{Tensión a compresión}

En los ensayos de resistencia a compresión, el valor obtenido para la probeta de referencia (100Y-70A-0F-0D-0G) ha sido 10,76 MPa tal y como se representa en la Tabla 4.
The boards were tested in accordance with the instructions contained in the Gypsum Acceptance Specifications Code. Although it has been repealed, this is the sole text that establishes a minimum bending strength for type E-30 plaster (the material used in this laboratory study) and is the reference cited by many other authors working in this field.

For industrially manufactured laminated gypsum board, the applicable Spanish standard would be UNE 520 (in effect since March 2007), which for type A-D-E-F-H-I board with a nominal thickness of $9.5 \mathrm{~mm}$ recommends failure loads of $160-\mathrm{N}$ (transverse) and $400 \mathrm{~N}$ (longitudinal). For type $R$ (improved strength) boards, the recommended values are 300 and $725 N$, respectively, and for type $P$ (gypsum bedplate) boards, 125 and $180 \mathrm{~N}$.

\subsection{Compressive strength}

In the compressive strength tests, the value found for the control specimen (100Y-70A-OF-OD-0G) was 10.76 MPa, which (Table 4).

Tabla 4 / Table 4

Comparativa de la resistencia a compresión para diferentes compuestos fabricados. Comparison of compressive strength for different compounds produced.

\begin{tabular}{|c|c|c|c|c|c|}
\hline $\mathbf{Y} \%$ & $\mathbf{A} \%$ & $\mathbf{F} \%$ & $\mathbf{D} \%$ & $\mathbf{G} \%$ & $\sigma$ compresión / $\sigma$ compressive MPa \\
\hline 100 & 70 & 2 & 0,5 & 0 & 8.21 \\
\hline 100 & 80 & 2 & 0,5 & 0 & 5.01 \\
\hline 100 & 90 & 2 & 0,5 & 0 & 5.18 \\
\hline
\end{tabular}

Tomando como referencia las exigencias mecánicas a compresión establecidas por la EN 13279 para los yesos de construcción, de $2 \mathrm{MPa}$, se puede apreciar que las prestaciones mecánicas de la probeta base superan con creces este valor, con lo que existe un gran margen para añadir otros agregados -en este caso, material de cambio de fase-, respetando los valores recomendados por la norma.
Amply exceed the 2-MPa requirement for compressive strength laid down in European standard EN 13279 for construction plaster. This left considerable room for adding other components, in this case phase change materials, while still meeting the recommended values. 
Este valor inicial aumenta al añadir más dispersión y disminuye con la mayor cantidad de agua, aunque existen unas proporciones entre los distintos elementos para las cuales se mejora la resistencia a compresión, fuera de las cuales disminuyen las prestaciones.

Al añadir PCM al conjunto, nos da los siguientes valores Tabla 5).
The aforementioned initial value rose when more dispersing agent was added and declined when more water was added, although batching was found to be instrumental to compressive strength, which rose with certain proportions but declined outside those values.

Adding PCMs to the mix yielded the following values (Table 5).

Tabla 5 / Table 5

Comparativa de la resistencia a compresión para diferentes compuestos fabricados con materiales de cambio de fase. Comparison of compressive strength for different compounds produced with PCMs.

\begin{tabular}{|c|c|c|c|c|c|}
\hline $\mathbf{Y} \%$ & A \% & F \% & D \% & G \% & o flexión / obending MPa \\
\hline 100 & 80 & 2 & 0.5 & 30 & 3.93 \\
\hline 100 & 90 & 2 & 0.5 & 30 & 3.19 \\
\hline
\end{tabular}

Un ligero incremento en la dispersión, hasta $1 \%$, mejora los resultados, para iguales proporciones del resto de los elementos.

Existen unas proporciones entre los distintos elementos para las cuales se mejora la resistencia a compresión, fuera de las cuales disminuyen las prestaciones. No es posible determinarlas con los ensayos realizados, y sería necesario realizar una investigación particularizada en determinar cuál es el efecto específico que produce cada adición y cómo afecta a los resultados de resistencia a compresión.

En este caso las líneas de tendencia que se obtienen de las gráficas (Figura 6 ) son también polinómicas, lo que indica que todos los elementos integrantes del compuesto influyen en los resultados del ensayo. Las parábolas de las curvas son muy abiertas, casi tendentes a rectas y convergen en unos valores comunes a medida que se incremente la proporción de PCM.

Se observa cómo en la adición de porcentajes más elevados de PCM al conjunto, la reducción de la resistencia a compresión es menor, donde la curva es casi paralela al eje X.

Así por ejemplo en las series que tienen un $80 \%$ de PCM se obtienen valores a compresión de más de 2,5 MPa, que se mejoran ligeramente cuanta más fibra tienen y disminuyen cuanta mayor es la proporción de agua en el compuesto.

En las series que contienen un $100 \%$ de PCM, este valor desciende hasta 2,21 MPa.

Todos estos valores son superiores a los exigidos por la norma.

La UNE EN 13279 exige al menos $2 \mathrm{MPa}$, por lo que todas las muestras realizadas serían válidas para trabajos en construcción.
The results improved when the dispersing agent was increased slightly, to $1 \%$, and the remaining components were left unchanged.

These proportions could not be determined with the tests conducted, for they would call for research specifically designed to determine the separate effect of each component on compressive strength.

The curves plotted were polynomial for compressive strength also, an indication that all the constituents affected the test results. The parabolas in these curves were very subtle, nearly straight lines that converged on common values with rising proportions of PCMs.

The inclusion of higher percentages of PCMs led to smaller declines in compressive strength and a curve running nearly parallel to the $X$-axis.

In the series containing $80 \%$ PCM, for instance, compressive strength values of greater than $2.5 \mathrm{MPa}$ were obtained. They improved slightly when more fibre was added and declined with higher proportions of water.

Compressive strength dipped to 2,21 MPa in the series containing $100 \%$ PCM.

All these values are higher than the minimum requirement set out in the standard, however.

Since European and Spanish standard UNE EN 13279 sets the minimum at $2 \mathrm{MPa}$, all the samples tested would be apt for use in construction: 


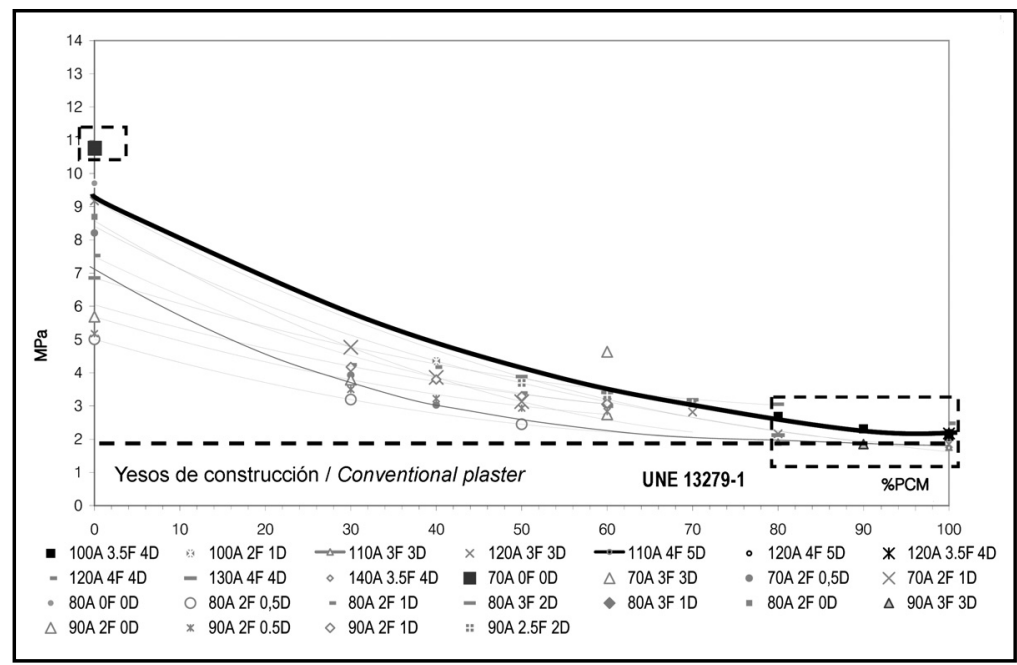

Figura 6. Resistencia a compresión: resultados obtenidos en las diferentes dosis. Se recuadra el valor de la probeta base $(A / Y, 0,7)$ y valores mínimos recomendados en la normativa de aplicación y se marca la línea de tendencia de la dosis elegida.

Figure 6. Compressive strength: findings with different dosages. The reference specimen $(A / Y=0.7)$ and minimum recommended value is framed and the trendline of the selected dosage is emphasized.

El aumento de la cantidad de PCM, así como de agua supone una disminución de la resistencia a compresión.

La adición de fibras y dispersión mejora la capacidad mecánica a compresión del compuesto.

\subsection{Análisis de las líneas de rotura}

De entre todas las muestras realizadas y ensayadas en el laboratorio se va a exponer el análisis de las líneas de rotura de la probeta $100 \mathrm{Y}-100 \mathrm{~A}-3,5 \mathrm{~F}-4 \mathrm{D}$ por ser la propuesta para industrializar, con lo cual la documentación gráfica aportada es más relevante si cabe que en el resto de probetas.

\subsubsection{Acabado}

Esta muestra, que contiene un porcentaje elevado de PCM y de fibras, aunque también mayor proporción de agua y dispersión, nos revela ciertos signos de perdida de trabajabilidad. Para estas dosis de agregados sería recomendable utilizar medios mecánicos que faciliten el amasado de los elementos y una distribución más homogénea de éstos en el compuesto final.

Superficialmente presenta un aspecto algo rugoso, por lo que quizás necesitaría una capa fina de acabado de escayola, que le devolviese una imagen más lisa y uniforme para poder utilizarse como elemento de acabado interior de un edificio (Figura 7).

Los bordes presentan cierta disgregación, debida a una insuficiente distribución del agua en esas zonas, que han dejado el conglomerante apenas mezclado con la fibra, por lo que no se ha producido todo el proceso de cristalización de la molécula de semihidrato.
Raising the amount of PCM and water lowered compressive strength.

Adding fibres and dispersing agents enhanced composite compressive strength.

\subsection{Failure line analysis}

Of all the samples prepared and tested in the laboratory, only specimen 100Y-100A-3.5F-4D-80G is analyzed hereunder for failure lines, as this is the specimen proposed for industrial production. Its respective graphic documentation is consequently more relevant than the documentation for the other samples.

\subsubsection{Finish}

This sample, which had a high percentage of both PCMs and fibres, as well as high proportions of water and dispersing agent, exhibited certain signs of loss of workability. For these dosages, mechanical methods would be recommendable to ensure thorough mixing and more uniform distribution of the components in the final composite.

Its somewhat rough surface may require a thin finishing layer of plaster to ensure the smooth, even appearance required for use in building interiors (Figure 7).

Some flaking was observed around the edges, due to the scant distribution of water in these areas, where the binder barely mixed with the fibre and as a result the semi-hydrated molecule failed to crystallize fully. 
Conserva la definición de aristas y planeidad de las caras, por lo que sería recomendable para fabricar placas, tabiques y piezas de pequeño y gran formato.

La parte posterior presenta algunas pequeñas irregularidades, lo que revela que la compactación de la masa ha sido insuficiente. Para estas cantidades de residuo seco, en relación al agua, tan elevadas, deberían utilizarse medios mecánicos de compactación, que permitiese que la masa, menos plástica, llegase a todas las esquinas.

\subsubsection{Ensayo a flexión}

En los resultados obtenidos aparecen fisuras en dos probetas, con algunas microfisuras superficiales, y algunas microfisuras en la probeta tres. Esto revela una distribución heterogénea de las fibras, por la dificultad de trabajar en el amasado (Figura 8).

Estos resultados son similares a los de las probetas sin dispersión, lo que hace suponer que se debería añadir más cantidad de ésta, no sólo para mejorar la trabajabilidad de la mezcla durante el amasado y aumentar el tiempo de fraguado, sino para obtener una distribución más homogénea de las fibras y recuperar el efecto sinérgico entre los diferentes agregados y su trabajo en conjunto.

En las tres probetas coincide la línea de fisura, situadas entre $-1 \mathrm{~cm}$ y $+1 \mathrm{~cm}$ respecto del centro de la cara más larga.

La fisura de la probeta 1 supera la mitad del grosor de la pieza, mientras que la 2 y la 3 apenas llegan a éste.
The sides and arris were clearly defined, making this material apt for manufacturing gypsum boards, partition walls and small- and large-scale plaster items.

A number of minor irregularities were observed on the back side, an indication that the mix was not thoroughly compacted. For such large amounts of dry matter compared to the amount of water, mechanical compaction methods should be used to ensure that this paste, less plastic than conventional plaster, reaches into all the corners of the mould.

\subsubsection{Bending test}

Cracks and surface microcracks appeared in two specimens, and a few microcracks in a third, denoting the uneven distribution of the fibres due to the scant workability of the paste (Figure 8).

As these results resembled the findings for the samples with no dispersing agent, they suggest that higher doses of agent are needed, not only to enhance paste workability and lengthen the setting time, but to ensure a more uniform distribution of the fibres, as well as the synergies among the components and their joint action.

The cracks were positioned in the same place on all three specimens, within $1 \mathrm{~cm}$ of the centreline of the longest side.

The crack in specimen 1 reached more than midway into the thickness of the panel, while in specimens 2 and 3 it barely reached the halfway point.

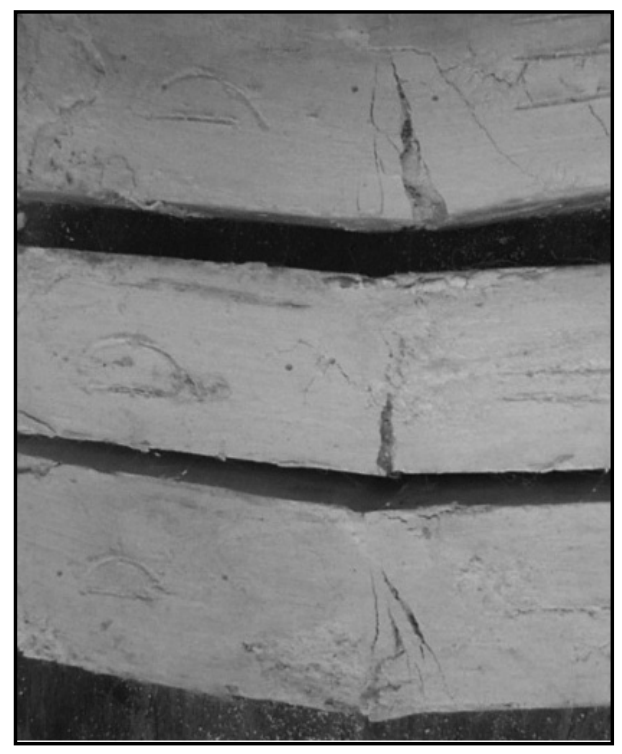

Figura 8. Análisis de la rotura a flexión de las tres muestras.

Figure 8. Bending failure analysis in three samples. 


\subsubsection{Ensayo a compresión}

Al igual que en el caso anterior, se observa la capacidad plástica de las probetas, es decir, su capacidad de deformación, sin llegar a la rotura (Figura 9).

Presenta ciertas descamaciones o laminaciones superficiales, aunque no tantas como la anterior serie, debido a la disminución de la relación de fluidificante, que ha recortado su periodo de deformación plástica. Se detecta en este ensayo, una vez más, la necesidad de aumentar la dosis de fluidificante, en pro de una mejora de las prestaciones físicas y mecánicas de la muestra.

Aparecen microfisuras junto a las huellas de la prensa de ensayo (Figura 10).

\subsubsection{Compression test}

As above, this test provided evidence of sample plasticity or strain capacity prior to failure (Figure 9).

The surface scaling in these specimens was less intense than in the preceding series due to the smaller dosage of dispersing agent, which shortened the plastic strain period. This test also identified the need to increase the dose of dispersing agent to improve the physical and mechanical characteristics of the sample.

Microcracks appeared alongside the marks left by the test frame (Figure 10).

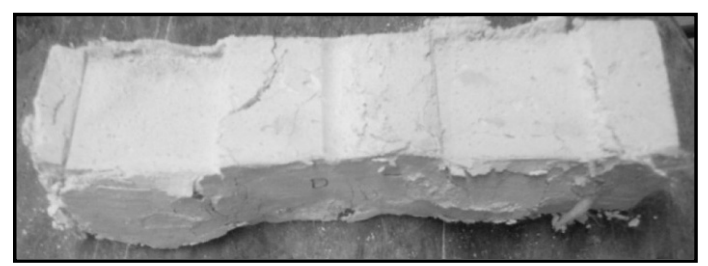

Figura 9. Imagen de una de las probetas tras el ensayo a compresión.

Figure 9 . One of the specimens after the compression test.

4.4.4. Análisis de las líneas de rotura en placas

4.4.4. Failure line analysis in gypsum boards

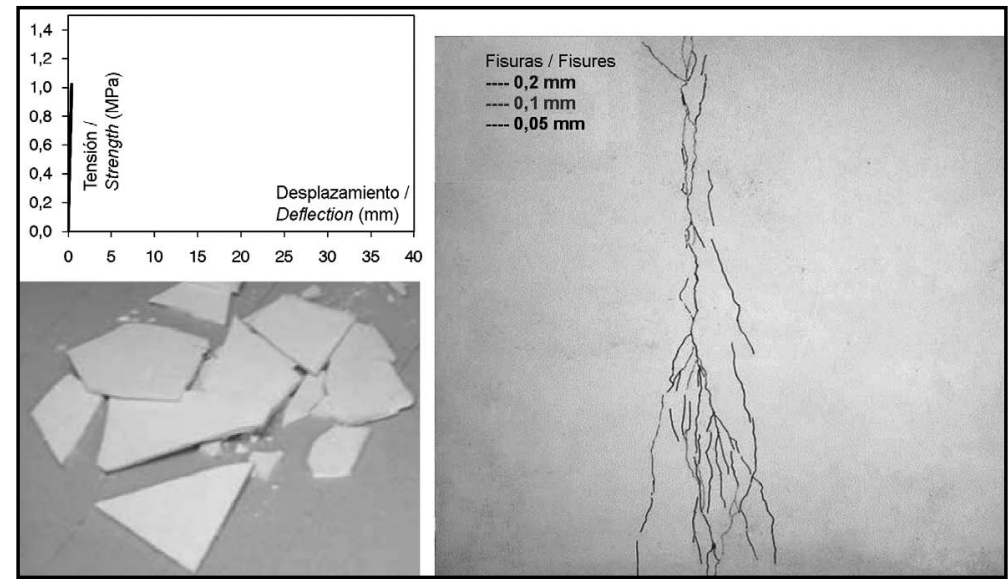

Figura 10. Comparación de la rotura de la placa de referencia (70A-100Y-0F-0D-0G) con la microfisuración producida en la placa (100A-100Y-3.5F-4D-80G) tras el ensayo a flexotracción en el laboratorio.

Figure 10. Comparison of failure in the control board (70A-100Y-OF-OD-OG) and microcracking in board 100A-100Y-3.5F-4D-80G after the laboratory bending test.

\section{CONCLUSIONES}

Se ha conseguido incrementar la tasa de PCM en paneles de yeso, de un $26 \%$ en peso, logrado en trabajos anteriores, a más de un $44,5 \%$ en peso, o lo que es lo mismo, en una placa de escayola de $1,5 \mathrm{~cm}$ de espesor, se ha incrementado la cantidad de menos de $3 \mathrm{~kg} / \mathrm{m}^{2}$ a $4,75 \mathrm{~kg} / \mathrm{m}^{2}$ que en términos energéticos supone un incremento de más del doble de capacidad de almacenamiento (para un incremento de temperatura de $10^{\circ} \mathrm{C}$ ).

\section{CONCLUSIONS}

The percentage of PCMs in gypsum panels was raised from the $26 \%$ wt previous maximum to over $44.5 \%$ wt. In absolute terms, in a $1.5-\mathrm{cm}$ thick plasterboard, the dosage was raised from under $3 \mathrm{~kg} / \mathrm{m}^{2}$ to $4.75 \mathrm{~kg} / \mathrm{m}^{2}$, for more than a two-fold increase in energy storage capacity (assuming a $10^{\circ} \mathrm{C}$ rise in temperature). 
Para ello se han incorporado previamente otros aditivos que mejoran las propiedades físicas y mecánicas del material compuesto.

Se ha elegido la dosificación 100Y-100A-3,5F-4D-80G para industrializar por ser la que con mayor cuantía de material de cambio de fase incorporado cumple las recomendaciones establecidas por la normativa, con lo que se asegura su correcta funcionalidad en los diferentes usos para los que han sido diseñados (los propios de yesos).

Las características físicas y mecánicas de la dosificación propuesta se comparan en la Tabla 6 con las de la dosificación de referencia (relación $A / Y 0,7$ ), y a su vez con la normativa de aplicación.
This was attained by including two additives that improved the physical and mechanical properties of the composite.

The 100Y-100A-3.5F-4D-80G composite was chosen for industrialization, inasmuch as it contained more phase change material than any of the others studied, while also meeting the recommended strength requirements. This would ensure its satisfactory performance in the uses for which it is designed (applications where plaster is characteristically used).

Table 6 contains a three-way comparison of the physical and mechanical properties of the control dose (water/gypsum ratio $=0.7$ ), the proposed dose and the applicable requirements.

Tabla 6 / Table 6

Comparación de las características físicas y mecánicas de la probeta de referencia $(A / Y=0,7)$ y los de la dosificación elegida para industrializar.

Physical and mechanical properties of the control dosage $(A / Y=0.7)$ and the dosage chosen for industrialization.

\begin{tabular}{|c|c|c|c|c|c|}
\hline & \multicolumn{2}{|c|}{ Ensayos físicos / Physical trial } & \multicolumn{3}{|c|}{ Ensayos mecánicos / Mechanical trial } \\
\hline Probeta / Specimen & $\begin{array}{c}\text { Reducción de peso / } \\
\text { Weight loss \% }\end{array}$ & $\begin{array}{c}\text { Densidad seca / Dry } \\
\text { density } \mathrm{g} / \mathrm{cm}^{3}\end{array}$ & $\begin{array}{c}\text { Dureza Shore C Ud I } \\
\text { Shore C hardness }\end{array}$ & $\begin{array}{l}\sigma \text { flexión media Mpa / } \\
\text { Mean bending } \sigma \mathrm{MPa}\end{array}$ & $\begin{array}{c}\sigma \text { compresión media } \\
\text { Mpa / } \\
\text { Mean compressive } \sigma \\
M P a\end{array}$ \\
\hline 100Y-70A-0F-0D-0G & 31.00 & 1.11 & 47.72 & 4.78 & 10.76 \\
\hline 100Y-100A-3,5F-4D-80G & 32.28 & 0.71 & 58.89 & 2.89 & 2.69 \\
\hline Normativa / Legislation & - & $>0.6$ & $>45$ & $>1.0-3.0$ & $>2.0$ \\
\hline
\end{tabular}

La reducción de peso tras el proceso de fraguado es sensiblemente superior a la de la probeta realizada con la mezcla de referencia, con lo que se pueden aplicar las mismas consideraciones que en el curado de un yeso convencional.

La densidad seca de este nuevo compuesto se reduce en un $38 \%$ respecto a un mortero de yeso convencional, es decir, de $1.100 \mathrm{~kg} / \mathrm{m}^{3}$ a $700 \mathrm{~kg} / \mathrm{m}^{3}$. Ello implica un aligeramiento de la placa de yeso con PCM frente a una convencional, con la consiguiente disminución del número de fijaciones mecánicas necesarias para su instalación y reducción de la carga a soportar por las estructuras.

Así, una placa de yeso con PCM propuesta pesa 10,45 $\mathrm{kg} / \mathrm{m}^{2}$, frente a $16,8 \mathrm{~kg} / \mathrm{m}^{2}$ que pesaría la placa de referencia $(A / Y=0,7)$.

La dureza Shore $\mathrm{C}$ ha mejorado notablemente respecto a la mezcla de referencia y supera el mínimo recomendado por la normativa de aplicación.

La resistencia a flexión y a compresión, pese a que han reducido considerablemente sus valores respecto a la probeta de referencia, son superiores a los mínimos recomendados por la normativa de aplicación (EN 13279), lo
Since weight loss after setting was appreciably higher in the specimen made with the control paste, the new material may be cured under the same conditions as conventional plaster.

The dry density of the new composite is $38 \%$ lower than in conventional gypsum paste: $700 \mathrm{~kg} / \mathrm{m}^{3}$ compared to $1100 \mathrm{~kg} / \mathrm{m}^{3}$. This lightening of the PCM-containing gypsum board compared to conventional plasterboard translates into a need for fewer mechanical anchors during installation and smaller loads on the structure.

Indeed, the proposed PCM-containing gypsum board weighs $10.45 \mathrm{~kg} / \mathrm{m}^{2}$, compared to $16.8 \mathrm{~kg} / \mathrm{m}^{2}$ for the control board (water/gypsum $=0.7$ ).

The Shore $C$ hardness value was higher than the recommended minimum and significantly higher than the value for the control mix.

While bending and compressive strength were substantially lower than in the control specimen, both values were higher than the minimum recommended in the applicable legislation (EN 13279). The material is 
que los hace aptos para cualquiera de los usos enumerados en la normativa, es decir, los propios de yesos de construcción.

Además estos valores son muy similares, por lo que un panel fabricado con esta dosis puede colocarse en cualquier posición: vertical sometida a esfuerzos de compresión u horizontal sometido a esfuerzos a flexotracción.

Se ha mejorado notablemente la forma de rotura pasando de una rotura frágil, sin apenas deformación, en la que se fragmenta la placa en varias piezas, a una rotura dúctil de gran deformación (superior a $35 \mathrm{~mm}$, que es el máximo de la prensa de ensayo), manteniendo la integridad total de la placa y con aparición de unas microfisuras no superiores a $2 \mathrm{~mm}$ en el área sometida al esfuerzo. Esto supone un gran aumento de la seguridad de uso del elemento constructivo frente a los esfuerzos a los que se someta, especialmente cuando se coloque como recubrimiento de techos.

Esta modificación de la forma de rotura se relaciona directamente con el aumento notable la tenacidad que ha sufrido el compuesto y con el aumento de la plasticidad del mismo que le confieren una gran capacidad de absorber grandes esfuerzos antes de alcanzar la rotura.

Respecto al comportamiento térmico del nuevo compuesto que justifique su fabricación y uso, en trabajos anteriores, tras realizar ensayos térmicos de paneles confeccionados con la dosis 100Y-100A-3,5F-4D-80G, se comprueba que una placa de $1,5 \mathrm{~cm}$ de espesor almacena cinco veces la energía térmica de un panel de cartón yeso con el mismo espesor y la misma cantidad que una fábrica de ? pie de ladrillo hueco, en el rango de temperaturas próximas a la de confort $\left(20-30^{\circ} \mathrm{C}\right)$.

Este nuevo elemento constructivo, combinado con estrategias pasivas (ventilación natural nocturna y captación solar diurna entre otras) es ideal para garantizar la inercia térmica en cualquier tipo de construcción, pero principalmente las realizadas con sistemas ligeros así como edificios de uso intermitente (oficinas, colegios, centros de ocio,...). Con ello se contribuye a la regulación térmica del ambiente interior $-\mathrm{y}$ por tanto a la mejora de las condiciones de habitabilidad-, y a la reducción del consumo energético del edificio derivado de la climatización (calefacción y refrigeración). consequently apt for any of the uses listed, i.e., construction applications where plaster is characteristically the material of choice.

Moreover, since the two strength values are similar, these plasterboards can be positioned either vertically, working under compression, or horizontally, absorbing bending stress.

The failure mode improved considerably in the new material. Rather than the brittle failure observed in the control, in which the boards broke into several pieces preceded by barely any deformation, it exhibited ductile failure preceded by significant deformation (over $35 \mathrm{~mm}$, the maximum provided for on the test frame), in which the entire board remained intact. Microcracks appeared, but only around the area where the force was applied, and none was larger than $2 \mathrm{~mm}$. This implies substantially greater safety of use and greater element reliability in its reaction to the forces to which it is exposed, particularly when used to clad ceilings.

This change in the failure mode is directly related to the considerably greater toughness of this new material compared to conventional plasterboard and to its greater plasticity that enables it to absorb substantial stress before failing.

The justification for the manufacture and use of this new composite, however, lies in its thermal behaviour. Prior studies to test gypsum boards made with the 100Y100A-3.5F-4D-80G material showed that in the 20-30 ${ }^{\circ} \mathrm{C}$ temperature range, a $1.5-\mathrm{cm}$ thick panel stores the same amount of thermal energy as half-foot hollow brick masonry and five times more than plasterboard of the same thickness.

This new construction material, combined with passive strategies (natural ventilation at night and capture of sunlight during the day, among others) is ideal for guaranteeing thermal inertia in any type of building, but primarily in lightweight systems and buildings characterized by intermittent use (offices, schools, leisure time premises). It contributes to thermal regulation in indoor environments, and consequently to improved habitability, and lowers HVAC-related energy consumption in buildings.

\section{BIBLIOGRAFÍA / BIBLIOGRAPHY}

(1) Abhat, A.: "Low temperature latent heat thermal energy storage-Heat storage materials", Solar Energy, 30 (4) (1983).

(2) Feldman D., B. D.; Hawes, D. and Ghanbari, E.: "Obtaining an energy storing building material by direct incorporation of an organic phase change material in gypsum wallboard", Solar Energy Materials (1991), pp. 231-242. 
(3) Hauer, A.: "Innovative Thermal Energy Storage Systems for Residential Use", Bavarian Center for Applied Energy Research, ZAE Bayern (2002), p. 8.

(4) Hawlader, M.; Uddin, M. and Khin, M.: "Microencapsulated PCM thermal-energy storage system", Applied energy, 74 (1-2) (2003), pp. 195-202.

(5) Heim, D. and Clarke, J. A.: "Numerical modelling and thermal simulation of PCM-gypsum composites with ESP-r", Energy \& Buildings, 36(8) (2004), pp. 795-805.

(6) Rudd, A. F.: "Phase-change material wallboard for distributed thermal storage in buildings", ASHRAE Transactions, 99 (2) (1993), pp. 339-346.

(7) Oliver, A.: "Incorporación de materiales de cambio de fase en placas de yeso reforzadas con fibras de polipropileno. Aplicación a sistemas de calefacción y refrigeración pasivos para almacenamiento de calor latente en edificios", Departamento de Construcción y Tecnología Arquitectónicas, Universidad Politécnica de Madrid, Madrid (2009), p. 376.

(8) Salyer, I. O.: "Dry Powder Mixes comprising Phase Change Materials", USA (1993).

(9) Bader, M.: "Microencapsulated Paraffin in Polyethylene for Thermal Energy Storage", New Zealand: The University of Auckland, School of Engineering, Department of Chemical \& Material Engineering (2002).

(10) Feldman, D.; Banu, D. and Hawes, D. W.: "Development and application of organic phase change mixtures in thermal storage gypsum wallboard", Solar Energy Materials and Solar Cells, 36 (2) (1995), pp. 147-157.

(11) Shapiro, M., et al.: "Thermal storage in drywall using, organic phase-change material", Passive Sol. J, 4 (4) (1987).

(12) Kedl, R. J. and Stovall, T. K.: "Activities in support of the wax-impregnated wallboard concept", U.S. Department of Energy: thermal energy storage researches activity review (1989), New Orleans, Louisiana, USA.

(13) Neeper, D. A.: "Thermal dynamics of wallboard with latent heat storage", Solar Energy, 68 (5) (2000), pp. 393-403.

(14) Khudhair, A. M. and Farid, M. M.: "A review on energy conservation in building applications with thermal storage by latent heat using phase change materials", Energy Conversion and Management, 45 (2) (2004), pp. 263-275.

(15) Ahmad, M.; B. A.; Sallee, H. and Quenard, D: "Experimental investigation and computer simulation of thermal behaviour of wallboards containing a phase change material", Energy and Buildings, 38 (2006), pp. 357-366.

(16) Stovall, T. K. and Tomlinson, J. J.: "What are the potential benefits of including latent storage in common wallboard?", Conference:

27. Intersociety energy conversion engineering conference, San Diego, CA, United States (3-7 Aug, 1992).

(17) Feustel, H. and Stetiu, C.: "Thermal performance of phase change wallboard for residential cooling application", Laurence Berkeley National Laboratory, LBL-38320 (1997).

(18) Athientis A. K.; L. C. Hawes, D.; Banu, D. and Feldman, D.: "Investigation of the thermal performance of a passive solar test-room with wall latent heat storage", Building and Environment (1997), pp. 405-410.

(19) Darkwa, K. and Kim, J.: "Dynamics of energy storage in phase change drywall systems", International Journal of Energy Research, 29 (4) (2005), pp. 335-343.

20) Ibáñez, M., et al.: "An approach to the simulation of PCMs in building applications using TRNSYS". Applied Thermal Engineering, 25 (11-12) (2005), pp. 1796-1807.

(21) www.basf.com (cited 2010 20/02/2010).

(22) García-Santos, A.: "Comportamiento mecánico de yeso reforzado con polímeros sintéticos". Informes de la Construcción, 40 (397) (1988), p. 67.

(23) García-Santos, A.: "Caracterización de compuestos de escayola reforzados, en relación con el tipo de refuerzo y la relación a/y", Informes de la Construcción, 56 (2004), pp. 19-31. 